\title{
Atypical presentation of anti-Ma2-associated encephalitis with choreiform movement
}

Nathalie Lamby, MD, Frank Leypoldt, MD, Jörg B. Schulz, MD, and Simone C. Tauber, MD

Neurol Neuroimmunol Neuroinflamm 2019;6:e557. doi:10.1212/NXI.0000000000000557

$\mathrm{Ma} 2$ antibody-associated encephalitis is an inflammatory brain disease that associates with a systemic tumor in more than $90 \%$ of patients, most commonly a testicular germ-cell tumor, lung cancer, or breast cancer. The Ma2 antibody-mediated autoimmune encephalitis presents mostly as limbic, mesodiencephalic, or brain stem encephalitis. Cranial MRI often detects T2-hyperintense lesions that may progress to atrophy. However, other areas of the CNS, such as the brainstem, the thalamus, the hypothalamus, the cerebellum, or the basal ganglia may also be affected. Approximately one-third of patients with Ma2 antibody-associated encephalitis initially show no abnormalities in MRI. Roughly two-thirds of cases present abnormalities in the CSF, such as pleocytosis, protein increase, and positive oligoclonal bands. ${ }^{1}$ In cases of paraneoplastic encephalitis, tumor therapy is crucial for improvement and prognosis. Immunotherapy using high-dose IV steroids, IV immunoglobulins, plasma exchange, rituximab, and cyclophosphamide is recommended. ${ }^{2,3}$ Here, we present an unusual clinical presentation of a Ma2-associated autoimmune encephalitis.

\section{Case report}

A 72-year-old Caucasian woman, a retired librarian, presented with a 2-year history of memory deficits and mood instability, as well as uncontrollable right arm movements in the past year. She had increasing difficulty remembering the content of conversations and often misplaced items. She was becoming progressively nervous and anxious. Symptoms suggestive of temporal lobe epilepsy were denied. Because of the depressive mood, the patient was prescribed a medication with mirtazapine, and she reported no other medication. The patient had a medical history of osteoporosis and scoliosis.

On examination, there was a permanent chorea of the right arm (video) and mild sensory polyneuropathy. Neuropsychological testing demonstrated a mild multimodal cognitive impairment with deficits in memory, attention, executive function, and semantic fluency and mild depressive symptoms. Cranial MRI showed moderate microangiopathy and atrophy of the left hippocampus without contrast enhancement, and the EEG revealed epileptic potentials over the left temporal lobe. Diabetes and thyroid dysfunction were excluded, and ceruloplasmin level and antinuclear antibodies were within the normal range. CSF analysis showed a normal cell count and normal total protein, and isolated oligoclonal bands were present. $A \beta 40$ and $A \beta 42$, their ratio as well as tau and phospho-tau protein in the CSF were normal. Genetic testing failed to detect a mutation consistent with Huntington disease or other genetic disorders associated with choreatic disease (Huntingtin, PRNP, NKX2-1, ADCY5, FRRS1L, GNAO1, PDE10A, ATM). Paraneoplastic Ma2 antibodies were detected in serum using commercially available primate tissue-based assays and antigenspecific line blots (Euroimmun, Lübeck). PET—CT did not show evidence of a tumor. The patient was treated with $1 \mathrm{~g}$ methylprednisolone iv over 3 days followed by $1 \mathrm{mg} / \mathrm{kg}$ bodyweight prednisolone, slowly tapered over 3 months. Anticonvulsive therapy with lacosamide $100 \mathrm{mg}$ b.i.d. was initiated. No immediate response was noted.

\author{
Correspondence \\ Prof. Tauber \\ stauber@ukaachen.de
}

MORE ONLINE

- Video 
Nine months later, chorea and cognitive dysfunction were unchanged and the patient was no longer taking lacosamide. Repeat neuropsychological testing showed a similar profile compared with earlier testing. Cranial MRI remained unchanged and Ma2 antibodies were still detectable in serum. The EEG continued to demonstrate epileptic activity in the left hippocampal region. Repeat whole body PET-CT did not show any malignancy. The patient did not want a symptomatic therapy for the movement disorder.

\section{Discussion}

Ma2 antibody-associated encephalitis typically presents as limbic, mesodiencephalic, or brain stem encephalitis. Single cases of cerebellar ataxia, myelopathy, or radiculoplexopathy have been described. ${ }^{1}$ Symptoms of limbic encephalitis include memory impairment, behavioral or mood disorders, as well as new-onset epileptic seizures. Our patient with a to date nonparaneoplastic Ma2-associated syndrome developed chorea in the right arm in addition to classic symptoms of limbic encephalitis. Choreiform movement disorders have been described frequently in association with other autoimmune encephalitis, in particular, NMDA and CV2/CRMP5 antibodyassociated encephalitis. ${ }^{4,5}$ Choreiform movement disorders can also be associated with other diseases such as systemic lupus erythematosus, anti-phospholipid syndrome, Wilson disease, thyroid dysfunction, or diabetes. ${ }^{6}$ In the context of $\mathrm{Ma} 2$ antibody-associated encephalitis, there is, to our knowledge, only one comparable case of a movement disorder associated with $\mathrm{Ma} 2-\mathrm{Ab}$ in an Iranian male patient. ${ }^{7}$ In our patient, we interpreted the failure of improvement by steroids because of the already long duration of the disease symptoms. By this time, the active inflammation of the limbic encephalitis had probably already subsided. For this reason, we decided against further immunosuppressive therapy. We conclude that the atrophy of the hippocampus is the result of limbic encephalitis, leading to symptomatic epilepsy and persistent neuropsychological deficits. In conclusion, autoimmune etiology should be considered in patients with chorea, especially in the presence of cognitive dysfunction and antineuronal antibody screening initiated.

\section{Acknowledgment}

The authors thank Karmele Olaciregui Dague for English wording support.

\section{Study funding}

No targeted funding reported.

\section{Disclosure}

N. Lamby reports no disclosures. L. Leypoldt served on the scientific advisory board for Roche, Biogen, received travel funding and/or speaker honoraria from Grifols, Teva, Biogen, Fresenius, Bayer, Roche, Novartis, Merck, Roche, performs commercial antibody testing for University Hospital Schleswig. J. Schulz served on the scientific advisory board for Novartis, MSD, received travel and speaker honoraria from Pfizer, Novartis, Lilly, Bayer, served as editor in chief for Journal of Neurochemistry, served on the editorial board for Synapse, eNeuro. S.C. Tauber served on the scientific advisory board for Roche and received travel and speaker honoraria from Novartis, Teva, Merck, Roche and Biogen. Disclosures available: Neurology.org/NN.

\section{Publication history}

Received by Neurology: Neuroimmunology \& Neuroinflammation January 1, 2019. Accepted in final form February 27, 2019.

Appendix Author contributions

\begin{tabular}{|c|c|c|c|}
\hline Name & Location & Role & Contribution \\
\hline $\begin{array}{l}\text { Nathalie } \\
\text { Lamby, } \\
\text { MD }\end{array}$ & $\begin{array}{l}\text { Department of } \\
\text { Neurology, RWTH } \\
\text { University Hospital, } \\
\text { Aachen, Germany }\end{array}$ & Author & $\begin{array}{l}\text { Patient care, drafting } \\
\text { the manuscript, editing, } \\
\text { review of the literature }\end{array}$ \\
\hline $\begin{array}{l}\text { Frank } \\
\text { Leypoldt, } \\
\text { MD }\end{array}$ & $\begin{array}{l}\text { Institute of Clinical } \\
\text { Chemistry and } \\
\text { Department of } \\
\text { Neurology, University } \\
\text { Hospital Schleswig- } \\
\text { Holstein, Kiel, } \\
\text { Germany }\end{array}$ & Author & $\begin{array}{l}\text { Critical review of the } \\
\text { manuscript, intellectual } \\
\text { contribution }\end{array}$ \\
\hline $\begin{array}{l}\text { Jörg B. } \\
\text { Schulz, } \\
\text { MD }\end{array}$ & $\begin{array}{l}\text { Department of } \\
\text { Neurology, RWTH } \\
\text { University Hospital, } \\
\text { Aachen, Germany }\end{array}$ & Author & $\begin{array}{l}\text { Patient care, } \\
\text { contribution to } \\
\text { manuscript editing }\end{array}$ \\
\hline $\begin{array}{l}\text { Simone C. } \\
\text { Tauber, } \\
\text { MD }\end{array}$ & $\begin{array}{l}\text { Department of } \\
\text { Neurology, RWTH } \\
\text { University Hospital, } \\
\text { Aachen, Germany }\end{array}$ & Author & $\begin{array}{l}\text { Manuscript concept } \\
\text { and design, critical } \\
\text { review of the } \\
\text { manuscript, editing of } \\
\text { the final text }\end{array}$ \\
\hline
\end{tabular}

\section{References}

1. Dalmau J, Graus F, Villarejo A, et al. Clinical analysis of anti-Ma2-associated en cephalitis. Brain 2004;127:1831-1844.

2. Rosenkranz S, Friese M. Assoziierte Antikörper sind entscheidende Marker für Pathogenese und Prognose. Neurologie Psychiatrie 2015;17:38-46.

3. Prüß H. Neuroimmunologie: Neues zur limbischen Enzephalitis. Akt Neurologie 2013;40:127-136.

4. Gable M, Glaser C. Anti-N-Methyl-d-Aspartate receptor encephalitis appearing as a new-onset psychosis: disease course in children and adolescents within the California encephalitis project. Pediatr Neurol 2017;72:25-30.

5. Vigliani MC, Honnorat J, Antoine JC, et al. Chorea and related movement disorders of paraneoplastic origin: the PNS EuroNetwork experience. J Neurol 2011;258: 2058-2068.

6. Ghika J. Abnormal movements and internal medicine pathologies. Rev Med Suisse 2018;14:892-894.

7. Etemadifar M, Salari M, Badiee H, Mirmosayyeb O. Anti-ma2 receptor encephalitis mimicking Huntington chorea. J Res Med Sci 2017;22:31. 


\section{Neurology \\ Neuroimmunology \& Neuroinflammation}

\section{Atypical presentation of anti-Ma2-associated encephalitis with choreiform movement Nathalie Lamby, Frank Leypoldt, Jörg B. Schulz, et al. \\ Neurol Neuroimmunol Neuroinflamm 2019;6; \\ DOI 10.1212/NXI.0000000000000557}

This information is current as of April 1, 2019

\section{Updated Information \& Services}

References

Citations

Subspecialty Collections

Permissions \& Licensing

Reprints including high resolution figures, can be found at:

http://nn.neurology.org/content/6/3/e557.full.html

This article cites 7 articles, 0 of which you can access for free at: http://nn.neurology.org/content/6/3/e557.full.html\#\#ref-list-1

This article has been cited by 2 HighWire-hosted articles: http://nn.neurology.org/content/6/3/e557.full.html\#\#otherarticles

This article, along with others on similar topics, appears in the following collection(s):

Chorea

http://nn.neurology.org//cgi/collection/chorea

Information about reproducing this article in parts (figures,tables) or in its entirety can be found online at:

http://nn.neurology.org/misc/about.xhtml\#permissions

Information about ordering reprints can be found online: http://nn.neurology.org/misc/addir.xhtml\#reprintsus

Neurol Neuroimmunol Neuroinflamm is an official journal of the American Academy of Neurology.

Published since April 2014, it is an open-access, online-only, continuous publication journal. Copyright

Copyright (C) 2019 The Author(s). Published by Wolters Kluwer Health, Inc. on behalf of the American

Academy of Neurology.. All rights reserved. Online ISSN: 2332-7812.

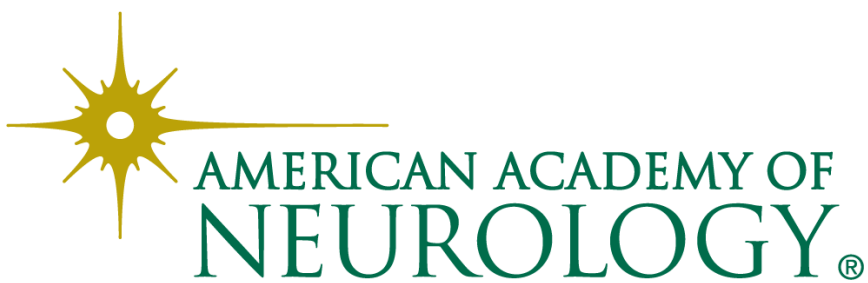

